DOI 10.38129/ Ann.Yur.Ist.2019.3.3.4.51

УДК 930.85:904: 323.269.6:321.011.1(32.019.51)

\title{
ПЕРВЫЙ ФРАНКО-ВИЗАНТИЙСКИЙ КОНФЛИКТ: АНАЛИЗ СОБЫТИЙ 550-х гг.
}

\author{
ВИКТОР МЕЛЬНИК (Киев, Украина)*
}

Год от Рождества Христового 552-й был полон испытаний для всех народов Евразии.

На Дальнем Востоке образовалось могущественное государство Тюркский каганат. В различных формах это образование просуществовало вплоть до 744 г. В 552 г. тюрко-алтайский Мугань-каган не только уничтожил кагана жужжаней Анахуаня (520-552 гг.), но и взял под контроль всю монгольскую степь, современные Алтай и Маньчжурию. Новая страна раскинулась от Желтого до Аральского моря. Тюрки вступили в соприкосновение с Персидской империей, угрожая теперь Кабульской долине и нагорью Ирана.

В том же 552 г. племена сабиров, некогда союзные гуннам, получили от византийского императора Юстиниана (527-565) lex foedus на захват Кавказского региона. В частности, тюркизированные угры сабиры захватили Каспийскую Албанию (современный Азербайджан) и стратегический Дербентский проход, где создали союзное официальному Константинополю федератское царство. Сабиры успешно воевали с Сасанидским Ираном и оказали большую помощь византийскому полководцу Бессе в сражениях с персами при Петре и в отдельных районах Месопотамии.

В 552 г. полным ходом шла христианизация кельтских народов Британии и Ирландии. Руководил этой стратегической операцией монах Колумбан, предпочитавший римскому епископату юрисдикцию Константинопольской церкви. Во всяком случае, Византия вступила в культурно-политическое соприкосновение с Ирландией и Уэльсом, тесно связанными с бывшей римской провинцией Арморика (теперь Бретань во Франции).

Тогда же, в 552 г. наступил исход семнадцатилетней войны остготов и византийцев, развернувшейся на всём протяжении Апеннинского полуострова и захватившей близлежащие области Прованса, Галлии, Алеманнии, Норика, Паннонии и Далмации... Побочным, но чрезвычайно 
важным для европейской истории результатом византийско-остготской войны, безусловно, стал конфликт между франкскими королями из династии Меровингов и византийским императором Юстинианом.

Зимой 551/552 гг. византийские легионы нанесли сокрушительное поражение славянским отрядам антов и склавинов, а также усмирили лангобардов и гепидов. Уже весной 552 г. Юстиниан отдал приказ 35тысячному корпусу Нарсеса выступить в поход на Италию. Поскольку область Венетии контролировалась франкскими дружинами короля Теодебальда Меровинга, Нарсес должен был совершить свой пеший переход таким образом, дабы уйти от возможного столкновения с «франкскими дикарями». Известно, что в этом византийскому генералу помогали проводники из осажденного Тотилой (541-552 гг.) гарнизона Равенны.

Византийские историки не зря восхваляли военное искусство генерала Нарсеса. Понимая, что переход через перевалы Истрии (современной Словении) чреват не только горными засадами, но и потерей стратегического времени, полководец развернул корпус боевым порядком и совершил быстрый поход вдоль берега Адриатического моря. С одной стороны, такой порядок позволял войскам держаться вместе и не рассеиваться. С другой стороны, Нарсес мог рассчитывать на помощь византийского флота и немедленную эвакуацию в случае чрезвычайного происшествия. Именно флот доставил фураж и амуницию в порт Равенны. Вслед за боевыми кораблями, в Равенну вошло и само войско Нарсеса ${ }^{1}$

Современник событий Прокопий Кесарийский высоко оценивает полководческий талант Нарсеса, проявившийся в истрийском переходе. Уход Нарсеса от прогнозированного столкновения с меровингскими отрядами привел остготское общество к «унынию духа и ума»². Внутренняя оппозиция не дремала, готовясь к путчу против диктата Тотилы. Как и в 542 г., Тотиле теперь нужна была победоносная битва. В конце июня 552 г., в центральноитальянской долине Busta Gallorum, состоялось величайшее сражение VI века, в результате которого остготская армия прекратила организованное существование, а сам Тотила погиб. Напомним слова хрониста Ландольфа: «Нарсес убил короля Тотилу, который царствовал уже свыше десяти лет; окровавленные же его одежды и корона, украшенная драгоценными камнями, были отосланы в царственный град Константинополь и брошены к ногам императора в присутствии сената»³.

\footnotetext{
${ }_{1}$ Procop. BG, IV.26.24.

2 Procop. BG, IV.26.4.

${ }^{3}$ Landolf., XVIII.19.
} 
Как это уже было двенадцать лет тому назад, в мае 540 г., остатки остготской армии спешно отступили на север от р. По, где королем на совете старейшин избрали сподвижника Тотилы Тейю. Он немедленно начал переговоры с франкскими правителями Теодебальдом и Хлотарем ${ }^{4}$. Они затребовали выплаты золота и территориальных уступок. Впрочем, колеблющаяся позиция Теодебальда Меровинга склонилась к оказанию помощи остготам, главным образом, из-за опасения перед византийским вторжением в Прованс. В итоге, франки Теодебальда оккупировали город Верону и окрестности, но дальше не двинулись.

Нарсес знал о переговорах между Тейей и Теодебальдом. Возможно, ему передавали информацию разведчики. Допускаем также помощь византийцам со стороны Хлотаря, скрыто ненавидевшего родного племянника Теодебальда. Этим можно объяснить ту уверенность, с которой Нарсес покорял остготские крепости в южной Италии, совершенно открыв линию фронта на севере.

Потеря Рима и символический обряд восстановления императорской власти в Италии 5 , совершенный Нарсесом, привели разрозненные остатки остготской армии в отчаяние. Остготы приступили к массовым убийствам латиноязычного населения, уповая на помощь Теодебальда' ${ }^{6}$ Однако, меровингский король, хотя и получил от Тейи «авансом» Верону, вежливо отказал остготскому «коллеге» в дальнейшей военной помощи и посоветовал ему сдаться «на милость императора римского». Напуганный отсутствием франкской помощи, остготский флот в полном составе сдался Нарсесу. Тейя, раздосадованный франкской вероломностью, предпринял смелую вылазку в центр Италии, где в октябре 552 г. проиграл битву возле Молочной горы.

Соглашаясь с академиком 3. В. Удальцовой, Тейю вполне можно и нужно характеризовать в качестве последнего великого короля германской древности. Он погиб вместе со всей своей армией. Оборванные и голодные остатки остготских войск сражались с византийцами после смерти своего короля больше суток. В результате, они отвоевали у Нарсеса перемирие на таких условиях: остготы признавали высшую власть византийского императора, а самого Нарсеса новым правителем Италии; торжественно клялись никогда не вступать в боевые действия против подданных Восточной Римской империи; соглашались поселится на север от р. По. Эти

\footnotetext{
${ }_{4}^{4}$ Procop. BG, IV.33.7.

${ }^{5}$ Procop. BG, IV.33.13-27.

${ }^{6}$ Procop. BG, IV.34.2-6.
} 
условия касались одной тысячи остготов, выживших во время битвы ${ }^{7}$

Октябрьское соглашение остготов и византийцев (552 г.) прекратило организованную борьбу остготского племени против Византийской империи. Смелый военачальник Тейя удостоился чести быть последним королем восточных готов - выходцев из Причерноморских и Балатонских степей. Ни один человек не сумел больше добиться возвышения в среде разрозненных и униженных остготских дружинников. Ни один человек в среде германских племён времен Великого переселения народов не представил большего примера эпического героизма и целеустремлённости. Остготские короли Теодорих Великий (493-526), Амаласунта (534-535), Витигис (536-540), Тотила (541-552), Тейя (552) являются самыми яркими представителями германского мира не только VI века, но и всего раннего средневековья. В истории германоязычных племен трудно найти личности, больше влиявшие на судьбы не только Восточной Римской империи, но и всего мира. Эта сентенция касается и остготского народа в целом...

Впрочем, героическая тысяча остготов, отсупившая на север, по соглашению с Нарсесом, сразу же поделилась на два враждующих лагеря. Немногочисленная, но воинственная группа созвала военный совет, преследуя цель отомстить Юстиниану. Трезво оценивая ничтожность собственного политического положения, оставшиеся в живых остготы решили выслать депутацию к одному из меровингских королей с «официальным» приглашением занять остготский трон и завоевать Апеннинский полуостров.

Франки с завистью смотрели на богатства древней Италии и не без злорадства наблюдали за военными поражениями остготов. В 537 г. они отобрали у остготов Прованс, Лигурию и большую часть Венетии. В 552 г. подразделения короля Теодебальда оккупировали Верону. Таким образом, франки контролировали все альпийские перевалы и былые торговые переходы, а также рассчитывали получить выход к Адриатическому морю.

Остготское посольство, прибывшее к «трусливому и больному» королю Теодебальду 8 , озвучило опасение, что вначале византийцы полностью уничтожат народ остготов, а потом примутся «вырезать» франков. Остготские легаты склоняли Теодебальда Меровинга на свою сторону, говоря о том, что следующей целью Восточной Римской империи

\footnotetext{
7 O соглашении см.: Procop. BG, IV.35.37; Agn., 79; Mar. Avent., a. 552, a. 553. 8 Agath., I.6.
} 
станут разрозненные и враждующие королевства франков ${ }^{9}$. В случае, если франки не нанесут упреждающий удар, Нарсес окрепнет и аннексирует Австразию. Хронист Агафий Миренейский написал, что послы подчеркнули: в случае такого захвата «у византийиев не будет недостатка $b$ законных поводах для прикрытия своеи жадности... Поэтому они будут прикидываться не насильниками, а ведущими справедливую войну, не ищущуими чужого, но возвращуающими владения своих римских предков»10.

Летописец Агафий акцентирует, что король Теодебальд склонялся к поддержке остготов очень долго. Как видим, франки отказались помочь остготам даже в момент наибольшего напряжения сил (речь о сражениях 552 г.). Это дает повод считать политику франков не столько «нездоровой» или «слабой»11, сколько целенаправленной и выжидательной. Очевидно, Теодебальд «безучастно» смотрел на противоборствующие стороны с целью добиться их максимального ослабления. Этот момент настал в самом конце 552 г.: армия остготов погибла, в то время как армия Нарсеса чрезвычайно устала и нуждалась в свежем пополнении. Учитывая потенциальную слабость Нарсеса, Теодебальд отдал приказ готовиться к войне ${ }^{12}$. Но война, как пишет хронист Агафий, не была объявлена. Повременив и спросив совета у старейших военачальников, Теодебальд решил пойти тем путем, который использовался еще в 537-539 гг., когда франки вторглись в остготскую Лигурию - путем применения «добровольческих дружин», юридически не имеющих отношения к меровингским королям.

Теодебальд начал рекрутацию соответствующих «добровольцев» из среды военнообязанных австразийцев, алеманнов, бургундов и тюрингов. Эти отряды Теодебальд поделил на две армейские группировки под командованием родных братьев, алеманнов по происхождению, Бутилина и Левтариса. Алеманнский вельможа Бутилин еще в 540-х гг. командовал франкскими соединениями на землях Венетии ${ }^{13}$. Именно его войска угрожали Нарсесу при пешеходном истрийском марше вдоль адриатического берега.

Заметим, что командование король поручил алеманнским полководцам для того, чтобы избежать последующих византийских

9 Здесь очевиден намек на политическое противостояние франкских королей Теодебальда и Хлотаря.

10 Agath., I.5.

11 Agath., I.6.

12 Agath., I.6.

13 Greg. Tur. Hist. Franc., III.32. 
претензий к франкам. Теодебальд, в случае неудачи, сознательно ставил под удар зависимые от него племена алеманнов.

Историк Павел Диакон в своей «Истории лангобардов» особенно подчеркивает роль Теодебальда Меровинга в собирающемся походе. В частности, Павел Диакон пишет, что Теодебальд тайно готовился к оккупации Апеннинского полуострова. Когда войска Бутилина и Левтариса уже вступили в Италию, Бутилин постоянно отсылал награбленное имущество королю Теодебальду14. Численность войска (75 тысяч франков и алеманнов!) говорит в данном случае сама за себя. Разве возможно было в те времена собрать такую огромную массу способных носить оружие мужчин, без ведома и разрешения непосредственного правителя региона?

С другой стороны, Теодебальд и не мог объявить войну Византийской империи, поскольку де-юре считался её подданным ${ }^{15}$. Здесь опять же проявляется тонкая юридическая грань между ведением войны внешней и войны внутренней в эпоху поздней античности / раннего средневековья.

Франки не были равны византийцам. Поэтому они могли нападать только без открытого объявления военных действий. В этом контексте, поведение Теодебальда и поход Бутилина-Левтариса обладают общими признаками вооруженного мятежа. Для ясности подчеркнем: кем бы не считал себя сам правитель локального христианского варварского королевства поздней античности или раннего средневековья, византийский император рассматривал его как вассала или губернатора вверенной провинции. Во многих случаях варварским королям приходилось соглашаться с такой формальной юридической трактовкой собственной власти (вести летоисчисление с упоминанием византийских консулов, пользоваться монетои с изображением императора, не чеканить золотых монет, упоминать имя императора на празднествах и литургиях, использовать римские титуль и звания), поскольку это позволяло обезопасить себя от потенциального военного вмешательства искуссных византийских полководцев, а также придавало особой законности правлению. Таким образом, императорская власть, сама того не осознавая, становилась юридическим источником для обустройства собственных политических структур варварскими королями раннесредневековой Европы. Вот почему непосредственными командирами франкской армии в итальянском походе

\footnotetext{
14 Pauli Diac. Hist. Lang., II.2.

15 Мельник В. М. Замечания о международной правосубъектности варварских королевств Европы (V-VI века). Альманах міжнародного права. Одеса: ВД «Гельветика», 2019. Вип. 21. С. 3-12.
} 
являлись алеманнские вельможи.

Весной 553 года 75-тысячное отборное войско франков и алеманнов вступило в долину реки По. Агафий так описывает планы Левтариса и Бутилина: «Они полагали, что Нарсес не выдержит даже первого их натиска, что вся Италия вместе с Сииилией будет их достоянием»16.

В момент вторжения франко-алеманнов, Нарсес занимался осадой крепости Кумы, где оборонялся большой остготский гарнизон. В крепости находилась сокровищница короля Тотилы и обороняющиеся остготы рассчитывали сохранить её под своим контролем. Получив известие о франкской агрессии, Нарсес срочно занялся перегруппировкой сил. Он начал организованный отход в Тусцию, где надеялся измотать новых врагов ${ }^{17}$.

Под Флоренцией и в Центральной Италии византийцы Нарсеса натолкнулись на ожесточенное сопротивление малочисленных, но оперативно действующих остготских партизанских групп. Их активизация была, конечно же, связана с действиями Бутилина-Левтариса. Пользуясь отвлечением Нарсеса на ликвидацию партизанского движения, франки устроили жестокую резню византийских пограничных подразделений под Пармой 18 .

Силами равеннского гарнизона и, с помощью фракийских полков, Нарсес сдерживал продвижение основных сил франко-алеманнов вглубь Италии. Но человеческих резервов византийцам не хватало. И отдельные группы франков просачивались в разрушенную войной страну.

Кроме того, известия о поражении возле Пармы немедленно изменило расклад в отношениях между остготами и византийцами. Хронист Агафий объясняет: «Ибо готы, населяющие Эмилию и Лигурию и ближайшие места, раньше заключившие непрочный и неискренний мир и военный союз с римлянами, скорее устрашенные, чем добровольно, теперь немедленно перешли к варварам, будучи связаны с ними общностью нравов и быта»19. Франкские эмиссары проникали в контролируемые остготами крепости и районы, подстрекая вновь поднимать оружие тех, кто лишь недавно сдался на милость победителя. На этот раз остготским сопротивлением командовали исключительно франкские вожди. Именно меровингские посланники осуществляли непосредственное руководство большинством

\footnotetext{
${ }^{16}$ Agath., I.7.

17 Agath., I.11.

18 Agath., I.15.

19 Agath., I.15.
} 
укрепленных районов остготов северной Италии и партизанскими отрядами центральной Италии.

Впрочем, хотя остготы и ожесточились против византийцев, Нарсес сумел оперативно разгромить сопротивление главного укрепленного города остготов - Луки ${ }^{20}$.

В виду приближения зимнего периода, чувствуя непрочность интендантской системы снабжения, византийские командиры на совместном совете постановили отказаться от открытого генерального сражения с франко-алеманнской армией в текущем 553-м году. Летописец Агнелл пишет, что «возвратился Нарсес в Равенну с великой победой»21. Однако, не будем забывать, что решение Нарсеса перезимовать вместе со всей византийской армией за стенами крупнейших городов Италии, стало губительным для огромного количества жителей Апеннин. Итальянцы буквально были отданы на растерзание ордам франков и алеманнов. К тому времени поведение франков стало невыносимым даже для их союзников остготов.

Разгромив византийцев под Пармой, франки начали истреблять остготов к северу от р. По. Один из последних известных историографии остготских полководцев Алигерн, вместе с некоторыми подконтрольными отрядами, отказался помогать Бутилину и Левтарису и перешел на сторону Нарсеса. Он сказал, что «хитрые франки не пожелают возвратить готам Италию, но на деле прежде всего поработят их самих, которым на словах пришли на помощь, поставят над ними начальниками фрранков и ичшат их отечественных обычаев»22. Именно Алигерн в начале 554 г. вручил Нарсесу ключи от города Кумы, передал Нарсесу сокровищницу Тотилы и подтвердил приверженность октябрьскому соглашению 552 г. При этом, Алигерн ссылался на то, что Теодорих Великий (493-526) и Амаласунта (526534), хотя и были величайшими правителями остготов, однако целиком и полностью признавали себя подчиненными Восточной Римской империи 23.

Переход Алигерна на сторону Нарсеса поколебал многих франков. В обозе франко-алеманнов все чаще раздавались голоса о целесообразности продолжения войны. Ведь остготы теперь вступали в союз с византийцами, да и настичь византийские войска в открытом сражении не удавалось в

20 Agn., 79.

21 Agn., 79.

${ }^{22}$ Agath., I.20.

23 О юридической технике и процедуре такого признания см.: Мельник В. М. Римская империя в V веке. Крушение или перерождение? Наука и техника. Июль, 2019. №7 (158). С. 60-66. 
течение целого года. Получилось так: пока византийские воины зимовали в наполненных продовольственными запасами городах, поддерживающихся морским сообщением с Далмацией и Сицилией, франки были вынуждены скитаться по опустевшей территории Италии, везде встречая только разоренные деревни, горы непогребенных трупов да разбитые многолетней войной дороги. Вот почему среди подконтрольных франкам алеманнов, бургундов, варнов и тюрингов участились случаи дезертирства. В частности, вождь варнов Февдибальд все свое племя перевел на сторону византийцев, а себя самого, с позволения Нарсеса, провозгласил королем ${ }^{24}$.

Пока «добровольцы» Бутилина занимались грабежом Центральной Италии, его брат Левтарис скитался между неприступно укрепленными городами Апулии и Калабрии (на юге страны). В итоге Левтарис даже вышел на побережье Мессинского пролива. Агафий пишет: «франки кровью орошали святыни и оскверняли посевы, так что везде были разбросаны непогребенные трупы» 25 . Особенно франко-алеманны зверствовали в отношении духовенства. Их неуемная жестокость, по всей видимости, объясняется отсутствием ожидаемых больших богатств на итальянских территориях. Апеннины ведь полностью пришли в экономический упадок вследствии семнадцатилетней беспрерывной войны и экспроприаций остготского правительства Тотилы. Франкам приходилось грабить то, что не успели или не смогли ограбить остготы или византийские солдаты. Поэтому голод, болезни и деморализация стали уделом франкско-алеманнского похода 552-555 гг.

Тактика Нарсеса оправдывала себя. Пока византийцы контролировали все города Италии, отдыхали в укрепленных крепостях и наполняли продуктовые склады египетским и сицилийским зерном, франки просто блуждали пустынными землями в прошлом богатых аграрных провинций. Это должно было не только нарушить текущие планы варваров, но и создать отрицательную «рекламу» будущим вторжениям в Италию для всех племён разношерстного варварского мира. Как покажет дальнейший ход событий, на некоторое время урок, преподанный варварам Нарсесом, был усвоен.

Первым сдался Левтарис, прошедший огнём и мечом всю Италию от Альп до Мессинского пролива. Он повел свою армию назад, не вступая в столкновения с византийцами. Между Пезаро и Фано византийские полки армянина Артабана и гунна Улдаха разгромили вялые, голодные и

\footnotetext{
24 Agath., I.21.

${ }^{25}$ Agath., II.1.
} 
уставшие войска Левтариса. Большая часть захваченных франками в плен римлян сумела бежать, прихватив с собой многие награбленные Левтарисом богатства. Остатки 40-тысячного франкского корпуса позорно бежали в подконтрольную Теодебальду Венетию, где их настигло более суровое наказание - чума. От этой страшной болезни погибла практически вся армия и полководец Левтарис вместе с ней ${ }^{26}$.

Бутилин наблюдал за крахом армии родного брата со стороны. Он тоже разуверился в возможности победить византийцев и решил сделать карьеру остготского короля. Неизвестно, насколько действия Бутилина совпадали с приказами Теодебальда Меровинга, но он принялся агитировать остготов вновь восстать против Нарсеса и называл ошибкой предыдущие агрессивные действия франко-алеманнов по отношению $\mathrm{k}$ остготам северной Италии. Для пущей убедительности, Бутилин страшно расправлялся с остатками сельского населения Кампании (латиноязычного) и напоказ готовился к полевым битвам (а не осадам).

Лето 554 г. выдалось аномально жарким, вследствие чего византийцы продолжали выжидать благоприятного момента за стенами итальянских крепостей. Франки же вначале страдали от многочисленных болезней, а потом в их ряды пришёл страшный голод. Больше медлить было нельзя.

Наступление Нарсеса развернулось осенью 554 г. и окончилось сражением при Казилине (недалеко от Капуи). 30 тысяч франков и алеманнов столкнулись с 18-тысячным отрядом Нарсеса2 2 . Разгром франков был очень серьезный. Можно с уверенностью утверждать, что такого сильного поражения франки и алеманны еще никогда не испытывали.

Во-первых, византийцев было почти в два раза меньше (при этом, значительную часть корпуса Нарсеса составляли герулы, которые склонились на сторону Византийцев только тогда, когда перевес в сражении взяли восточные римляне).

Во-вторых, франкская пехота не могла противостоять византийской коннице ${ }^{28}$.

Бутилин погиб в бою, а остальные франки нещадно уничтожались византийцами. В частности, византийцы убили всех пленных, не щадя никого. Это объяснялось теми жестокостями и истинными варварствами, которые творили франки и алеманны в течение последнего года на итальянской земле. Агафий даже утверждал, что после битвы, из почти 30 тысяч фрранкских

\footnotetext{
${ }^{26}$ Agath., II.2-3.

${ }^{27}$ Agath., II.4-9.

${ }^{28}$ Agath., II.9.
} 
воинов, осталось в живых только 5 человек, которые «спаслись случайно» 29 . В любом случае, гибель армии Бутилина продемонстрировала силу византийцев целому варварскому миру.

Поражения, которые были нанесены официальным Константинополем сначала вандалам (533-534 гг.), потом остготам (540 и 552 гг.), затем франкам и алеманнам (553-554 гг.), надолго отбили охоту Меровингов завоевывать имперские провинции. В этом политическом смысле, война Нарсеса с франко-алеманнами на Апеннинском полуострове даже помогла дальнейшему укреплению мирной жизни в Италии, хотя урон, нанесенный франками и алеманнами итальянскому населению и народному хозяйству (в особенности древнему латинскому аграрному миру) был колоссальным.

Папский престол в своих письмах сообщал, что после разгрома Бутилина Нарсесом при Казилине «вся Италия пребывала в радости» ${ }^{30}$.

Если верить данным историка Агафия, то в Италии погибло не меньше 70 тысяч франков, бургундов и алеманнов. Так или иначе, но разгром этой варварской орды позволил византийцам окончательно удостовериться в своих силах. Они нанесли наконец сокрушительное поражение всем тем силам, которым не смогла противостоять Западная Римская империя. Византийцы под командованием Нарсеса сумели поставить зарвавшихся федератов на место. И меровингским франкам понадобилось еще очень много лет, прежде чем они смогли оправиться от итальянских утрат. В первую очередь, династия Меровингов бесповоротно загубила на итальянских полях сражений свой внешнеполитический авторитет.

В начале 555 г. Нарсес приступил к подчинению последних неподконтрольных районов Италии, занимаясь попутно централизацией собственной губернаторской власти. В частности, Нарсес организовал убийство последнего остготского военачальника Рагнариса, захватив принадлежавшую ему крепость Компс. Вся Южная и Центральная Италия оказались в руках императорской администрации. Теперь силы византийцев собирались на североитальянском направлении. Генерал Иоанн осуществил захват Лигурии ${ }^{31}$. В наказание за поход БутилинаЛевтариса, Иоанн также отвоевал земли, которые когда-то были уступлены Витигисом франкскому королю Теодеберту Меровингу.

\footnotetext{
${ }^{29}$ Agath., II.9.

${ }^{30}$ Lib. Pont. V. Iohan., III.2.

31 Agath., II.8.
} 
Франкам пришлось уйти с некоторых территорий, прилегающих к горным границам Южной Галлии ${ }^{32}$. Занимаясь организацией новой административной системы в Италии и восстановлением разрушенного хозяйства, Нарсес не осуществил завоевания Венетии. Эти территории фактически остались под контролем франков. Вероятно, что всё «франкско-византийское» перемирие (555г.) сводилось к признанию франками верховнои власти Юстиниана Великого. Только в обмен на это признание Нарсес мог оставить положение дел в Венетии на некоторое время таким, каким оно стало в результате сдачи провинции Витигисом и Тотилой ${ }^{33}$.

Хотя Лигурия и вся Северная Италия были взяты под контроль Нарсесом, оставался еще ряд городов, которые фактически являлись независимыми. Эти города уже не имели реальной и организованной остготской власти, но контролировались военными вождями из числа бывшей военной знати остготов. В частности, такими городами были Милан (сдался Нарсесу осенью 558 г.) $)^{34}$, Верона (взята византийскими войсками 20 июля 561 г.) $)^{35}$, Брешия (сдалась либо в 561 г. либо в ноябре 562 г.) $)^{36}$.

3. В. Удальцова пишет о завершающем этапе итальянской войны: «Столь длительное и упорное сопротивление, которое встретили византийцы $b$ Северной Италии, объясняется прежде всего тем, что здесь в большей степени, чем в других областях страны, сохранились поселения остготов и других варваров. Кроме того, в борьбе против византийцев принимали здесь участие и жители некоторых городских иентров Северной Италии. Агнел рассказывает, что византийским войскам пришлось сражаться не только с засевиими в Вероне остготами, но и с гражданами этого города»37.

«История лангобардов» Павла Диакона сообщает о том, что остготский вождь Видин, руководящий мятежной Брешией, пытался вновь призвать франков на Апеннины, но получил отказ Хлотаря I (511-561)38.

Когда Нарсес окончательно справился с отдельными очагами

32 Mar. Avent., a. 556.

33 Menandr., fr. 2. См. о «перемирии между Восточной Римской империей и Франкией»: Удальцова 3. В. Италия и Византия в VI веке. / 3. В. Удальцова. - М.: АН СССР, 1959. - с. 437.

$34 \mathrm{JK}, 983$.

35 Agn., 79.

${ }^{36}$ Malal., p. 492.

37 Удальцјова 3. В. Там же. - с. 438.

38 Pauli Diac. Hist. Lang., II.2. 
остготского сопротивления (555-562 гг.), у византийцев появилась возможность изгнать франков из некоторых итальянских регионов. Древняя римская провинция Венетия вновь перешла под римский политический контроль. Из «Хроники» Агнелла известно, что в августе 565 г. Венетия была уже полностью подконтрольна Восточной Римской империи ${ }^{39}$.

В свою очередь, хронист Марий Аваншский относит отвоевание Венетии восточными римлянами к 556 г.: «В этом году государственное войско римлян, восстановив силы, заняло ту часть Италии, которую завоевал король Теодеберт» ${ }^{40}$. То есть, Марий Аваншский считает, что отвоевание Венетии произошло по гарячим следам византийской победы над франко-алеманнами Бутилина и Левтариса.

По всей видимости, вторжение полков Нарсеса в Венетию действительно стало возможным в 555 г. - в момент меровингского междуцарствия на территории Австразии. В ноябре-декабре 555 г. Теодебальд Меровинг, после продолжительной болезни, умер. Его наследие тут же присвоил самый старший представитель династии, младший сын Хлодвига Хлотарь I. Этот король, владевший изначально регионами Тулузы, Суассона и Бордо, сумел сосредоточить в своих руках власть над большей частью современной Франции. В конце 555 г. его дружинники оккупировали Австразию, а сам Хлотарь женился на вдове Теодебальда. Этот шаг должен был придать законности завоеванию Хлотарем Австразийского королевства. Впрочем, епископы Суассона и Тулузы взбунтовались против нового брака своего правителя. Он оставил вдову Теодебальда, но владения покойного родственника объявил своей личной собственностью. Для пущей важности Хлотарь даже совершил объезд австразийской территории.

На почве аннексии Австразии развился конфликт между Хлотарем и другим сыном Хлодвига - королем Парижа Хильдебертом (511-558). К последнему даже перешел на службу родной сын Хлотаря Храмн. Смерть Хильдеберта (558г.) позволила Хлотарю завоевать север Франкии, в то время как Храмн попытался получить убежище во владениях бретонского графа Хонобера. В декабре 560 г. экспедиционный корпус Хлотаря разгромил Хонобера и бретонскую армию, а самого Храмна со всей семьей, по приказу родного отца, франкские дружинники сожгли заживо в деревенском доме.

Запутанный в алчных интригах и убийствах близких родственников,

\footnotetext{
39 Agn., 90.

40 Mar. Avent., a. 556.
} 
Хлотарь проиграл несколько сражений саксонским племенам, а рейнские земли (сердце Франкии) даже подверглись масштабному саксонскому вторжению. Против Хлотаря бунтовали аквитанские, бургундские, алеманнские и тюрингские вельможи. В регионе Северного моря и ЛаМанша активизировались датские пираты.

29 ноября 561 г. последний сын Хлодвига Хлотарь скончался в Компьене. Франки в тот момент переживали настоящий политический упадок, вследствие итальянского поражения, саксонской войны и начавшихся набегов кочевников-аваров. Пограничные полки Нарсеса стояли заставами у стен Сьона, Белле, Гренобля, Амбрёна, Диня и Ниццы. Можно с уверенностью утверждать, что, пользуясь междоусобицами, Нарсес захватил альпийские переходы Швейцарии и горные гряды Прованса. Де-факто, византийская власть начала распространение внутрь Меровингских владений. Особенно такому развитию событий способствовал раздел Меровингской Франкии на четыре части сыновьями Хлотаря.

Хариберт I получил Аквитанию и Север Франции, обозначив свои владения как Парижское королевство. Он правил с 561 по 567 гг.

Сигиберт I овладел «Австразийским королевством», оказавшимся разделенным на две большие части. На восток от реки Марны и Женевского озера, Сигиберту принадлежала вся современная западная часть Германии, а также территории Эльзаса и Лотарингии, включая Реймс, Верден, Страсбург, Майнц, Кёльн. К юго-западу от Женевы и бывшего Лионского королевства бургундов, Сигиберт контролировал Клермон, Жаволь, Веле, Родез, Изес и г. Экс в Провансе. Правил этот король с 561 по 575 гг.

Младший сын Хильперик получил Суассонское королевство, охватывавшее современные территории Бельгии и Нидерландов, а также племя фризских данников. Он руководил Суассонским королевством с 561 по 584 гг.

Бывшее Лионское королевство бургундов, включая Лион, Женеву, Безансон, Дижон, а также древний галльский Орлеан, возглавил Гунтрамн, правивший с 561 по 592 гг. ${ }^{41}$. Хотя столицу Гунтрамн разместил в Орлеане, свои владения он именовал «Бургундское королевство». Благодаря этой нехитрой политической стратегии, Гунтрамн заручился мощной поддержкой бургундской знати и возвеличил себя как «воссоздатель былого бургундского величия». Кроме того, Гунтрамн контролировал анклавы Арль и Ниццу, где еще в древние имперские времена

\footnotetext{
41 Дольше всех сыновей Хлотаря I (511-561).
} 
функционировали важнейшие морские порты и центры заключения торговых сделок.

Итак, в начале 562 г. Восточная Римская империя находилась в соприкосновении с границами Австразийского королевства Сигиберта и Бургундского королевства Гунтрамна. Передовые византийские разъезды теснили франкские дружины у австразийских городов Базель и Констанц, в то время как Гунтрамн был вынужден усиленно защищать Ниццу, Амбрён и Гренобль в Провансе.

В 561-565 гг. Нарсес занимался восстановлением сети крепостей и фортификаций на альпийских переходах и перевалах. Византийское присутствие в это время очевидно не только в североитальянских землях, но и на современных территориях Швейцарии и в пограничных с Италией районах Франции. Нарсес был сторонником построения нового аналога линии укреплений limes. Через секретариат Папы Римского Нарсес поддерживал хорошие отношения с бургундскими епископами, лионскими и арльскими клириками. Непосредственное дипломатическое общение помогало Нарсесу также в коммуникации с горными субэтносами алеманнского племени. Благодаря тонкой дипломатии итальянского губернатора, Австразия и Бургундия находились в перманентном политическом кризисе, а короли Гунтрамн и Сигиберт вынужденно лавировали между партией приверженцев полной независимости от франков и провизантийски настроенным католическим духовенством.

Генерал и патриций армянского происхождения Нарсес сохранял пост губернатора Италии вплоть до 568 г., когда он был уволен новым императором Византии Юстином II (565-578). Смерть императора Юстиниана Великого 14 ноября 565 г. стала великой трагедией не только для Нарсеса, но и для всего населения Италии. С этого времени официальный Константинополь обращал внимание на состояние дел на полуострове намного реже. Кроме того, Юстин II считал, что Нарсес слишком обогатился на занимаемой им должности, а это, в свою очередь, свидетельствует о возможности Италии управляться без субсидий и дотаций из императорского дворца.

Франкское направление внешней политики, как и вестготское, не составляло особого интереса для нового правителя. В итоге, Нарсес удалился в своё поместье близ Неаполя ${ }^{42}$, а треть Италии в 568-572 гг. была завоевана паннонским германоязычным племенем лангобардов. Центром завоевания стала северная Италия. В частности, лангобардам очень

42 Нарсес умер на своей вилле под Неаполем в 573 г. - на 96 году жизни. 
пригодились восстановленные Нарсесом альпийские крепости...

В любом случае, вторжение лангобардов отбросило византийские войска от непосредственной границы с королевствами франков и окончательно прекратило тлеющий вооруженный конфликт Меровингов и Восточной Римской империи.

Editor-in-Chief Viktor Melnyk (Kyiv, Ukraine)

FIRST FRENCH-BYZANTINE CONFLICT:

ANALYSIS OF THE HISTORICAL EVENTS OF THE 550's AD

The article is devoted to the history of the Frankish-Byzantine conflict of 552-556 that occurred against the backdrop of the weakening of Italy - a province of the Eastern Roman Empire. In 553-554 AD Alemanni, Burgundians and Franks invaded Italian territory under the leadership of Frankish military leaders. The author proves the knowledge of the Frankish king about this action and emphasizes the destructive nature of the unsuccessful expansion attempt by the Merovingian dynasty.

Keywords: Eastern Roman Empire (Byzantium), Italy, Narses, Ostrogoths, Franks, Merovingian Dynasty.

Виктор Мельник (Киев, Украина).

ПЕРВЫЙ ФРАНКО-ВИЗАНТИЙСКИЙ КОНФЛИКТ: АНАЛИЗ СОБЫТИЙ 550-Х ГОДОВ

Статья посвящена истории франкско-византийского конфликта 552-556 гг., произошедшего на фоне ослабления Италии - провинции Восточной Римской империи. В 553-554 гг. на территорию Италии вторглись алеманны, бургунды и франки под руководством франкских военачальников. Автор доказывает осведомленность франкского короля об этой акции и подчеркивает разрушительный характер неудачной попытки экспансии со стороны династии Меровингов.

Ключевые слова: Восточная Римская империя (Византия), Италия, Нарсес, остготы, франки, династия Меровингов.

Віктор Мельник (Київ, Україна).

ПЕРШИЙ ФРАНКО-ВІЗАНТІЙСЬКИЙ КОНФЛІКТ: АНАЛІЗ ПОДІЙ 550-Х РОКІВ

Стаття присвячена історії франксько-візантійського конфлікту 552-556 рр., що проходив на тлі чергового повоєнного ослаблення Італії - провінції Східної Римської імперії. У 553-554 pр. на територію Італії вторглися алеманни, бургунди і франки під керівництвом офіційних франкських воєначальників. Автор доводить обізнаність франкського короля про цю зовнішньополітичну акцію і підкреслює руйнівний характер невдалої спроби експансії з боку династії Меровінгів.

Ключові слова: Східна Римська імперія (Візантія), Італія, Нарсес, остготи, франки, династія Меровінгів. 
* Мельник Виктор Мирославович - главный редактор научного журнала «Анналы юридической истории», ассистент кафедры политологии философского факультета Киевского национального университета имени Тараса Шевченко, преподаватель кафедры философии и общественных наук Винницкого национального медицинского университета имени Н. И. Пирогова, член American Society for Legal History.

E-mail: melnyk1996ethnology@gmail.com. 